\title{
NEWS FROM OUR AFFILIATES
}

\section{CGMW PLENARY ASSEMBLY}

\author{
Paris, 13-27 March, 1978
}

Some 125 delegates from 49 countries discussed regional thematic maps and the worldwide projects of the Commission for the Geological Map of the World (CGMW): the Geologic World Atlas (1:10000 000) and the World Tectonic Map (1:15000 000). A very extensive exhibition of recent national and international maps covered some 100 linear meters in UNESCO Headquarters where the Plenary Assembly was held. Maps were also exhibited in the meeting rooms. The CGMW Bulletin 23 (available from the Secretariat, 51 Bd. de Montmorency, 75016 Paris, France) will summarize the discussions, give the recommendations adopted and a full list of the maps exhibited. The CGMW and its Subcommissions plan to meet at various places in the latter half of 1978, in 1979 and during the 26th International Geological Congress, when several maps projects will be displayed in final form.

A new aspect of CGMW compilations is the synthesis of data on continental margins and sea floor. The CGMW Working Group on Sea-Floor Mapping met to propose a legend for the off-shore areas of the new geological maps and of the World Tectonic Map. These proposals were discussed in the Plenary Assembly and met with foreseeable opposition from the continental geologists. The proposals will be applied to experimental drafts and discussed at later meetings. The main points are given briefly below.

A major feature of the earth's structure is the contrast between ocean and continental crust, and this should be reflected on maps by use of a continental and of an oceanic legend. Also, geophysical data should be fully exploited and interpreted. The W.G. strongly recommended that the general approach to geological maps of the deep oceans be that proposed by B.C. Heezen in 1970 (see ocean sheets, Geologic World Atlas) and stressed the following points:

- The continental margin to the foot of the continental slope should be shown on tectonic and geologic maps, with the legend used for the continents and in the same shades of colour; the shore line needs stressing.

- A series of subparallel lines (five lines shading) would indicate the boundary between continental and oceanic crust.

- Where continental sediments have spilled over the margin onto oceanic crust, the continental legend would be used and the isopachs be continuous with the on-margin sedimentary basins.

- Units for isopachs of sediments in the deep oceans should be in seconds, two-way travel time (thus eliminating the uncertainties inherent in transforming raw data).

- Whenever scale permits, character and age (radiometric when possible) of characteristic dredged and shallow core samples should be shown.

- Epicenters (magnitude 4 to 4.5 and over) and first motion resolutions (arrows) should be shown on geologic and tectonic maps (1:5000000 and over).

- Active and inactive faults should be differentiated and sense of movement given.

- Numbers and not ages should be assigned to magnetic lineations.

Among the new projects are the metallogenic map and mineral resources map $(1: 10000000)$ on the base of the Geologic World Atlas, and an Atlas of ore deposits of Europe.
The Metallogenic Maps of South America and of South and East Asia are making considerable progress. The metamorphic maps lag slightly behind, but that of Africa should be published in late 1978.

A new subdivision of the Precambrian prepared by V.E. Khain for the World Tectonic Map met subsequently with criticism by members of the IUGS Subcommission on Precambrian Stratigraphy. As IUGS bodies become increasingly map minded and are able to apply their special expertise to assist CGMW projects, their cooperation should be sought.

\section{Frances Delany}

Secretary-General, CGMW

Paris, France

\section{Wa00000000000000000000,000}

\section{EDITERRA: FOURTH GENERAL ASSEMBLY}

$$
\text { Detmold, FRG, 22-24 May, } 1978
$$

On the occasion of the Fourth General Assembly of the European Association of Earth-Science Editors (Editerra), a joint meeting was held with ELSE (European Life Science Editors Association) at the Federal Research Institute for Processing Cereals and Potatoes in Detmold, Federal Republic of Germany, to discuss the theme "Editing for Effective Scientific Communication - Practical Approaches".

Scientific sessions were primarily concerned with the practical measures which could be taken to improve and enhance present systems of scientific communication without increasing costs. The general topics covered included effective presentation of papers, style manuals, standards, the teaching of scientific writing, references, the relationship between primary and secondary publications, secondary services, computerized storage and retrieval of information, reproduction techniques, user and new publication methods. A full report on these sessions will be published in the July issue of the joint Editerra/ELSE newsletter Earth and Life Science Editing and enquiries regarding abstracts of papers read at the meeting should be directed to Miss Nancy Morris (Secretary), Bruins, 30 Longdown Road, Lower Bourne, Farnham, Surrey GU10 3JL, U.K.

During the Editerra General Assembly, the following members were elected to serve on the Editerra Council:

President:

Vice-Presidents:

Prof. S. Saxov (Denmark)

Past-President:

Secretary:

Treasurer:

Ordinary Members:

Dr. P. Fogelberg (Finland)

Dr. A.A. Manten (Netherlands)

Editor of Editerra

Handbook: Dr. J.W. Glen (UK)

Prof. Dr. K. Helbig (Netherlands)

Miss N.P. Morris (UK)

Mr. A.P. Harvey (UK)

Prof. G.M. Clayton (UK)

Mr. J. Gravesteijn (France)

The Closing Session was devoted to a discussion on the feasibility of an International Federation of Scientific Editors Associations (IFSEA) as proposed at the First International Conference of Scientific Editors in Jerusalem in 1977. The Council of Editerra submitted the following recommendations to the Meeting, based on safeguarding the interests and the existence of Editors' Associations:

(Continued on page 33 ..... 